\title{
The Dynamic Relationship between FinTech and Social Distancing under COVID-19 Pandemic: Digital Payments Evidence
}

\author{
Nader Alber ${ }^{1} \&$ Mohamed Dabour ${ }^{2}$ \\ ${ }^{1}$ Professor of Finance, Faculty of Business, Ain Shams University, Egypt \\ ${ }^{2} \mathrm{PhD}$ Candidate, Faculty of Business, Ain Shams University, Egypt \\ Correspondence: Nader Alber, Professor of Finance, Faculty of Business, Ain Shams University, Egypt. E-mail: \\ naderalberfanous@yahoo.com
}

Received: September 9, 2020

Accepted: October 14, 2020

Online Published: October 20, 2020

doi:10.5539/ijef.v12n11p109

URL: https://doi.org/10.5539/ijef.v12n11p109

\begin{abstract}
This paper investigats the opportunities of growth under restrictions of social distancing for FinTech. This has been conducted on 10 countries (United States, United Kingdom, Egypt, United Arab Emirates, Saudi Arabia, Japan, South Korea, Italy, India and Nigeria) during the period from March to June 2020. Results indicate that social distancing may affect digital payments. This has been supported for retail and recreation $\left(\mathrm{X}_{1}\right)$, grocery and pharmacy $\left(\mathrm{X}_{2}\right)$, transit stations $\left(\mathrm{X}_{4}\right)$ and workplaces $\left(\mathrm{X}_{5}\right)$, whithout any evidence about significant effects for parks $\left(\mathrm{X}_{3}\right)$ and residentials $\left(\mathrm{X}_{6}\right)$.
\end{abstract}

Keywords: COVID-19, Coronavirus, digital payments, FinTech, social distancing

\section{Introduction}

COVID-19 pandemic is a new type of coronavirus and it is a progressing worldwide pandemic of coronavirus illness. This has had many direct and indirect effects on human behavior and economic activity (Bartik et al., 2020; Nicola et al., 2020; Chetty et al., 2020). So, many billion people tend to continue their life in isolation (Beaunoyer et al., 2020) caring about social distancing to minimize physical contact between individuals and thereby to reduce the possibility for new infections. Internet-based communications seem to have the main role in ensuring a successful social distancing strategy.

As the COVID-19 crisis leads to create uncertainty, a lot of firms are under stress on a number of forehead. In the same time many companies of FinTech has an opportunities to grow under restrictions of social distancing. Access to funding has been already becoming difficult, especially for some early-stage ventures, focusing on established FinTech business models.

As COVID-19 breadths the world and disturbs the manner in which we connect and direct business, innovations can help by giving answers for keeping the required social distancing. By diminishing the reliance on physical money related communications and the requirement for money, FinTech can encourage government reactions and empower secure ways for governments and suppliers to arrive at weak populaces rapidly and productively (Appaya et al., 2020).

As social distancing has solidified globally, digital financial services and e-commerce have been increased in abnormal way (Beaunoyer et al., 2020). While we can't predict what form aftermath opportunities will take, we do notice that FinTech - a sector that is steeped in renovation - is likely to create new and conversional solutions.

It is obvious that social distancing is accelerating peoples' use of online - especially mobile - channels, to view and manage their cash. Because many FinTech applications are purpose-built for the mobile devices, they often surpass in offering presentation, onboarding, data visualization, and providing the right context for deals. These abilities will likely become even more relevant and important, as a greater number of financial transactions are managed through digital channels.

Characteristics of social distancing include healthy culture, governmental procedures, economic structure and supply chains. Besides, transactions volumes and values of digital payments may differ according to infrastructure of telecommunications sector, infrastructure of the banking sector, average income per capita, population, buying behavior and wareness and financial culture. 
COVID-19 spread may have winners in the field of IT, while many of its losers are in stock markets. Stock market reaction to announcement about Coronavirus spread has been addressed by many papers during 2020, where. This has been conducted by Alber (2020a) in the European stock markets, Alber (2020b) worst 6 countries (according to number of cumulative cases), Peterson and Ozili (2020) in major stock market indices, Alber and Saleh (2020) in stock markets of GCC countries and Smales (2020) in US Stock sectors.

This paper addresses a main question about the FitTech reaction to Coronavirus spread, where it investigates the effect of social distancing (in terms of Coronavirus spread) on digital payments (in terms of FinTec). This has been conducted on 10 countries (United States, United Kingdom, Egypt, United Arab Emirates, Saudi Arabia, Japan, South Korea, Italy, India and Nigeria) during the period from March to June 2020.

After this introduction, section 2 illustrates the theoretical framework of FinTech and Covid-19. Section 3 explains how to develop hypotheses and measure variables. Section 4 is for testing hypotheses and section 5 summarizes the paper and provides remarks about conclusions.

\section{FinTech and Covid-19}

This section is about the theoretical framework of the research topic, illustrating an overview about FinTech, discussing FinTech under challenge of COVID-19 pandemic and addressing FinTech and its future opportunities. After that, we have illustrated the elements of enabling FinTech and the responses for payment and settlement systems during the COVID-19 Crisis.

\subsection{FinTech: Overview}

FinTech is the innovation and development that expects to rival conventional money related strategies in the conveyance of financial services. It is a rising industry that utilizes innovation to improve exercises in financial services. The utilization of mobile app and other derives for portable banking, contributing, getting financial services, and cryptocurrency are types of advancements meaning to make financial services more available to the overall population. FinTech has been assuming an expanding job in forming financial and banking scenes (Jagtiani \& Lemieux, 2017).

At the point when technology and innovation put its fingers in the financial services, FinTech has been conceived, as a major trend of financial innovation. Presently, with this word allude to e-payment, e-transfers, crowdfunding (Chishti, 2016; Jiang et al., 2018; Hendriyani \& Raharja, 2019), crowdsource (Kunz \& Muralidhar, 2017; Camacho et al., 2019; Sul, 2020), peer-to-peer system (Chishti, 2016; Puschmann, 2017; Mahardhika \& Inggis, 2017; Guild, 2017; Jiang et al., 2018; Goldstein et al., 2019) and cryptocurrencies (Goldstein et al., 2019) refer to FinTech. Besides, Pavarotti et al. (2018) and Thakor (2020) address financial innovations in terms of incremental strains and intensified competition, the retail payments market remains a vital driver for the entire banking sector.

\subsection{FinTech under Challenge of COVID-19 Pandemic}

Beyond COVID-19: New opportunities for FinTech firmss and how FinTech are facing the COVID-19 challenge For instance:

a. PayPal has conceded fees on chargebacks and immediate funds from PayPal business accounts to bank accounts.

b. Lending Club has added new suffering plans, including waiving late fees and allowing competent borrowers to make interest-only payments or exceed up to two monthly payments.

c. Square is waiving software subscription fees for Square Payroll customers.

d. Stripe is fast-tracking support for telemedicine platforms.

e. Flock, a drone insurance provider, is allowing its commercial customers to pause their policies when no work is being conducted.

f. Kabbage worked with other FinTech like Lendio, Finix, and Fundera to launch a platform that allows consumers to buy gift certificates to support local small businesses during the coronavirus pandemic. The gift certificates can be redeemed at any time, but small businesses receive the revenue within one business day of purchase.

g. Nomo, a platform that assists freelancers in controlling their accounts, taxes, and invoices, is providing free temporary access to its fresh patrons.

h. 7 Chord, the company behind the BondDroid AI engine that generates prices for corporate bonds, offering its services in temporary freely. 
i. Revolut, conducted recently in the United States, and a number of other fintechs have introduced a charitable-giving feature within their apps which let customers can donate funds to those affected by COVID-19.

j. In the UK, Wiserfunding, Nimbla, Trade Ledger, and NorthRow have formed a business-lending taskforce to provide a warder origination and underwriting platform that allows banks, alternative lenders, and private debt lenders to virtually and digitally spread finances to businesses during the COVID-19 setting fire.

k. Israeli FinTech firm Innovesta launched its COVID-19 Resilience Innodex (CRI). Using a proprietary artificial intelligence technology, the CRI assigns risk scores based on a business' ability to combat the effects of a pandemic such as COVID-19.

1. iwoca, an online lender, announced OpenLending, a platform that allows fintechs and banks to extend iwoca's lending abilities to more than two million UK businesses.

m. nCino has a dvanced a new solution to optimize the PPP loan operation.

$\mathrm{n}$. Lendio is enabling small enterprises to apply for personal loans.

o. Unqork improved a small business digital lending platform.

p. Numerated, another digital lending platform is seeing an increase in banks' interest in using its technology to manage the rise in loan demand.

\subsection{FinTech and Future Opportunities}

FinTech entities may be obliged to reexamine their mission and business models after COVID-19. A prominent question is how to leverage both existing and newly developed assets to capture new opportunities in the coming decades. It could be a suitable time to think big and act boldly.

a. Improving Partnership Strategies: As a result of COVID-19, FinTech may continue acceleration of partnerships with financial entities, which can offer the benefits of capital, distribution, and compliance infrastructure, but often affect sought-after digital solutions.

b. Adopting Financial Inclusion Scenarios: The economic confusion of the pandemic is shedding light on the importance of serving individuals who are currently outside the financial system, both in developing and developed areas. According to the World Bank, there are 1.7 billion unbanked persons all over the world. It is possible that COVID-19 may lead to major financial inclusion as a result of recent government programs all over the world to help low-income households.

c. Accelerating Economic Relief Efforts: Many payments institutions may be well positioned to help in the more rapid expenditure of government relief funds, especially to those unbanked. Square, Venmo, PayPal, Finix, Plaid, Marqeta, and others - in addition to payroll-processing companies like Gusto - may play a big role in the coming times.

d. Exploiting the Internet of Things: Another area is Internet of Things (IoT), that enable contactless payments, such as connected cars that allow consumers to pay for gas or food without handling cash or other potentially infected surfaces. COVID-19 tend to accelerate the adoption of IoT-enabled payments.

\subsection{The Elements of Enabling FinTech}

The Bali FinTech paper consist of 12 policy proposals and cover issues related to enabling FinTech; ensuring financial sector resilience; addressing risks; and promoting international cooperation. These elements are (International Monetary Fund and World Bank; 2018):

e. Embrace the promise of FinTech.

f. Enable new technologies to enhance financial service provision.

g. Reinforce competition and commitment to open, free, and contestable markets.

h. Foster FinTech to promote financial inclusion and develop financial markets.

i. Monitor developments closely to deepen understanding of evolving financial systems.

j. Adapt regulatory framework and supervisory practices for orderly development and stability of the financial system.

k. Safeguard the integrity of financial systems.

1. Modernize legal frameworks to provide an enabling legal landscape. 
m. Ensure the stability of domestic monetary and financial systems.

n. Develop robust financial and data infrastructure to sustain fintech benefits.

o. Encourage international cooperation and information-sharing.

p. Enhance collective surveillance of the international monetary and financial system.

\subsection{The Responses for Payment and Settlement Systems During the COVID-19 Crisis}

According to World Bank, there a seven types of responses for the provision of payment services during the COVID-19 crisis, as follows:

a. Changes to KYC and authentication requirements.

b. Promoting and ensuring availability of digital payment mechanisms.

c. Consumer protection measures and ensuring availability and acceptance of cash.

d. Changes to Cybersecurity.

e. FMI risk management (including operational reliability).

f. Cash / Cheque usage restrictions.

g. Relaxation of Compliance requirements.

\section{Data Describtion and Developing Hypotheses}

This study has been conducted on 10 countries (United States, United Kingdom, Egypt, United Arab Emirates, Saudi Arabia, Japan, South Korea, Italy, India and Nigeria) during the period from March to June 2020.

Social Distancing has been measured by community mobility reports to COVID-19, by daily data according to a country, for retail and recreation $\left(\mathrm{X}_{1}\right)$, grocery and pharmacy $\left(\mathrm{X}_{2}\right)$, parks $\left(\mathrm{X}_{3}\right)$, transit stations $\left(\mathrm{X}_{4}\right)$, workplaces (X5) and residentials (X6). Digital payments are measured by transactions volumes $\left(\mathrm{Y}_{1}\right)$ and transactions values $\left(\mathrm{Y}_{2}\right)$.

Community Mobility Reports aim at providing reflexing into the improvements that have arisen in response to COVID-19 pandemic battle policies. This report is based on data recording over time by geography, across various categories of places. This report illustrates a percent change from baseline (14 February 2020). That includes six categories: Retail and Recreation; Grocery and Pharmacies; Parks; Transit Stations; Workplaces and Residential

Figure 1 illustrates social distancing measures in 10 countries from 14 February to 25 July 2020, as follows:

\section{In United States}

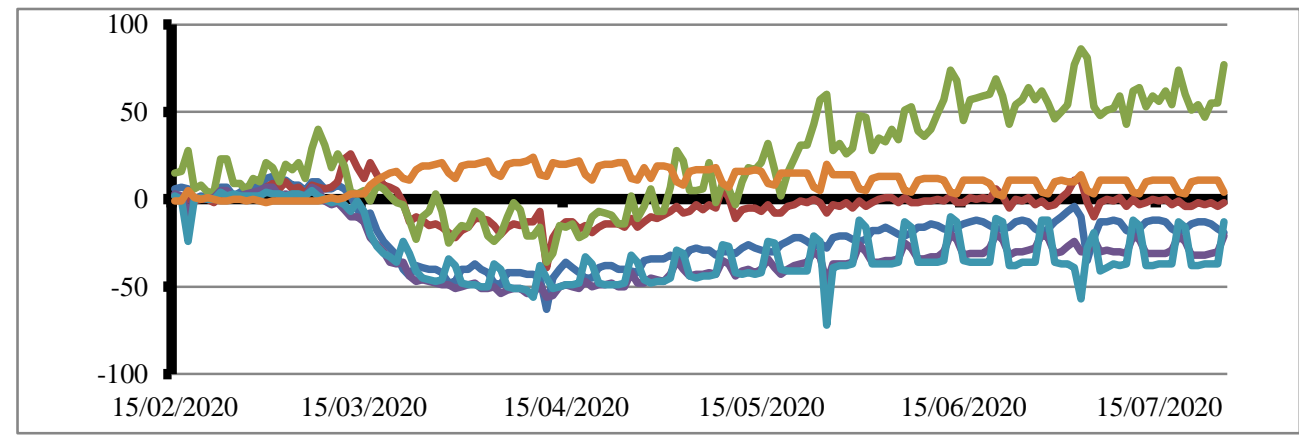

In Egypt

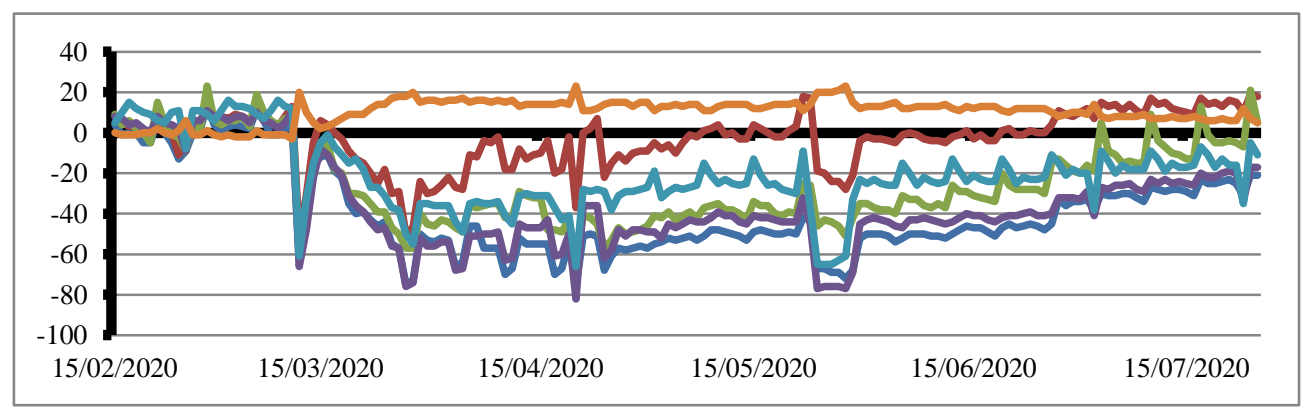


In United Kingdom

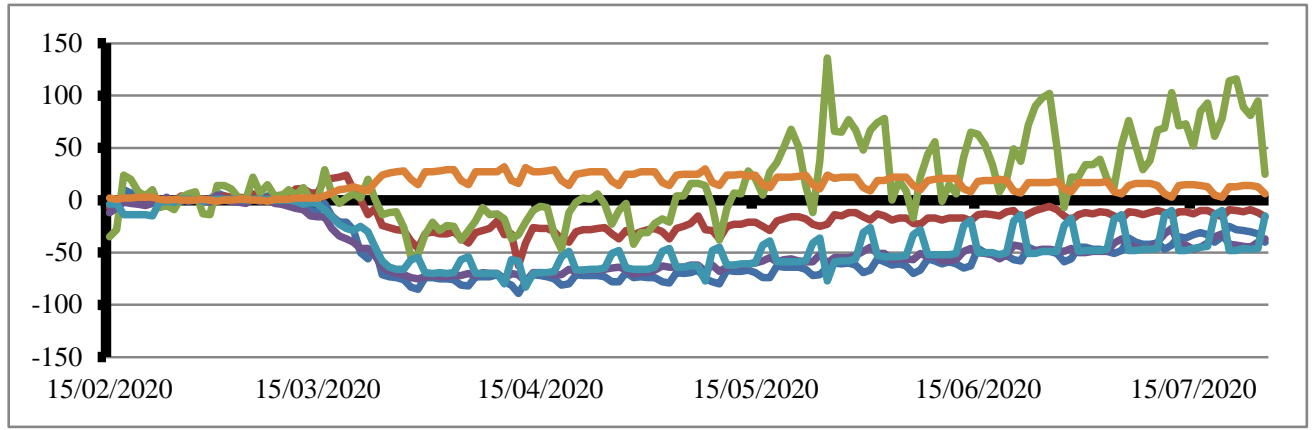

In United Arab Emirates

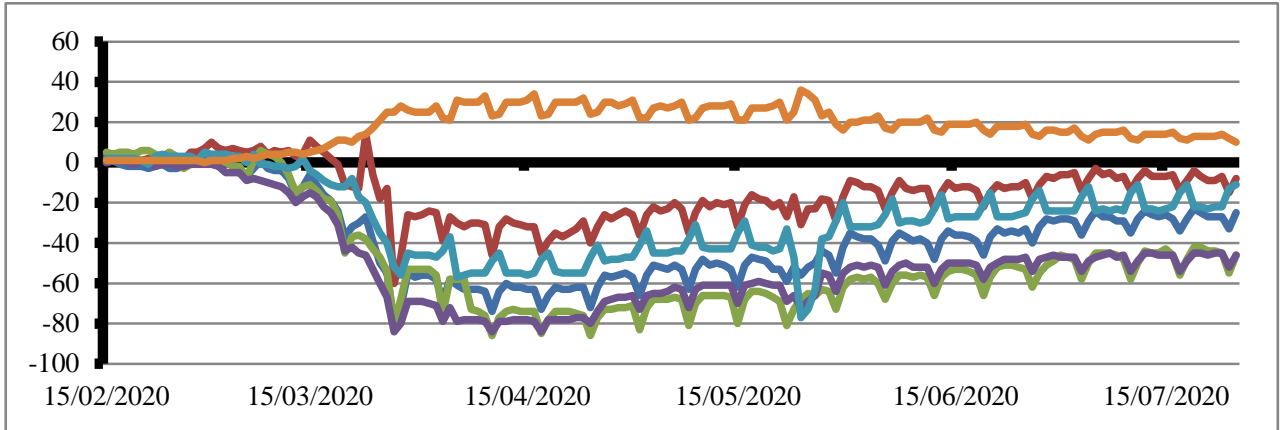

In Saudi Arabia

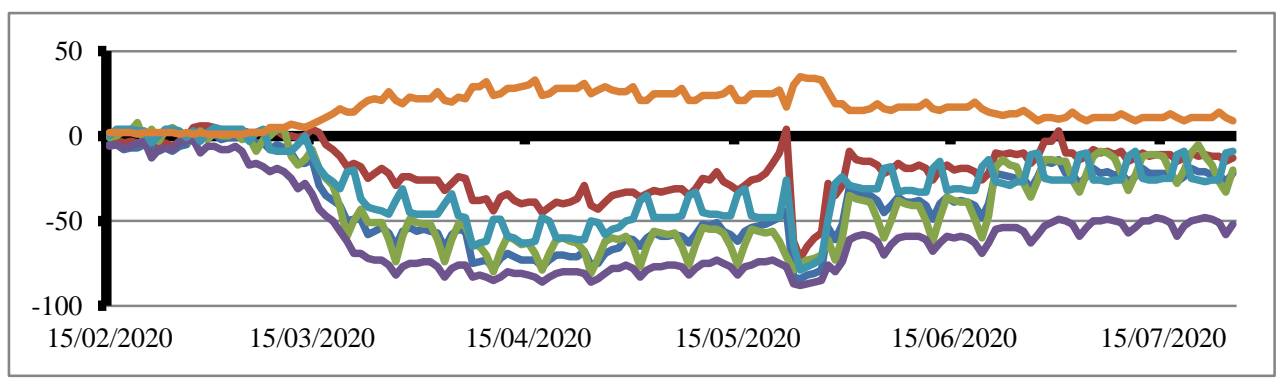

In Japan

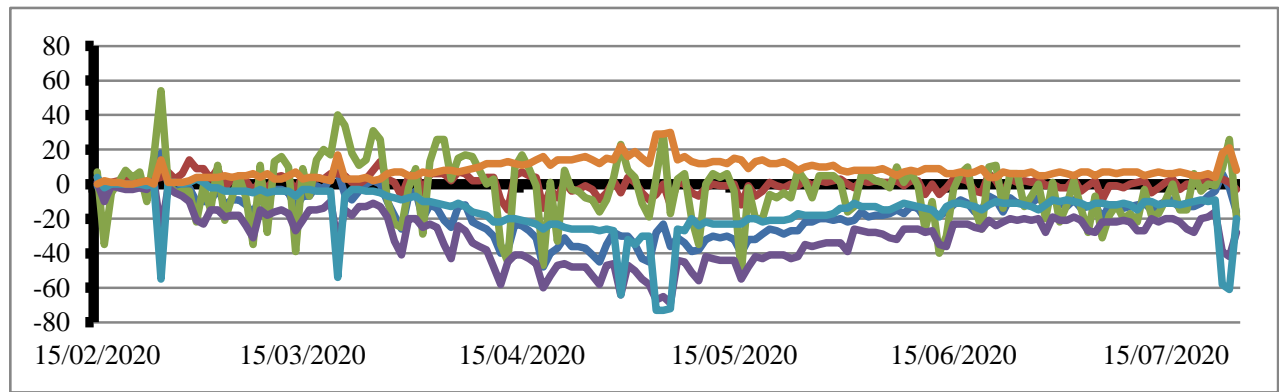

In Italy

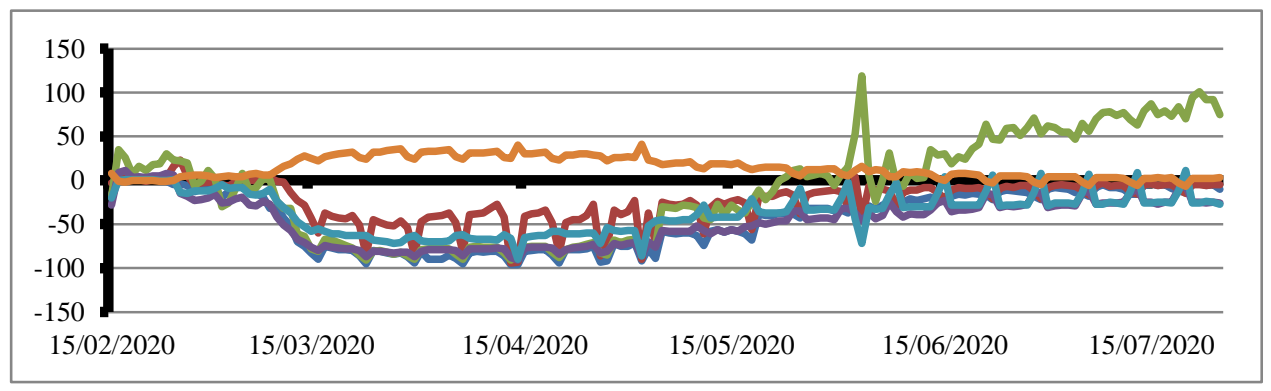


In South Korea

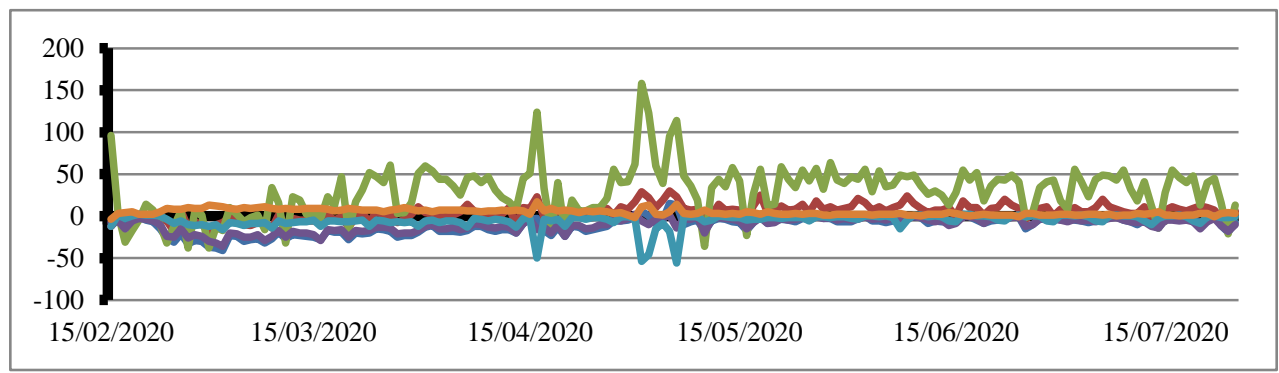

In India

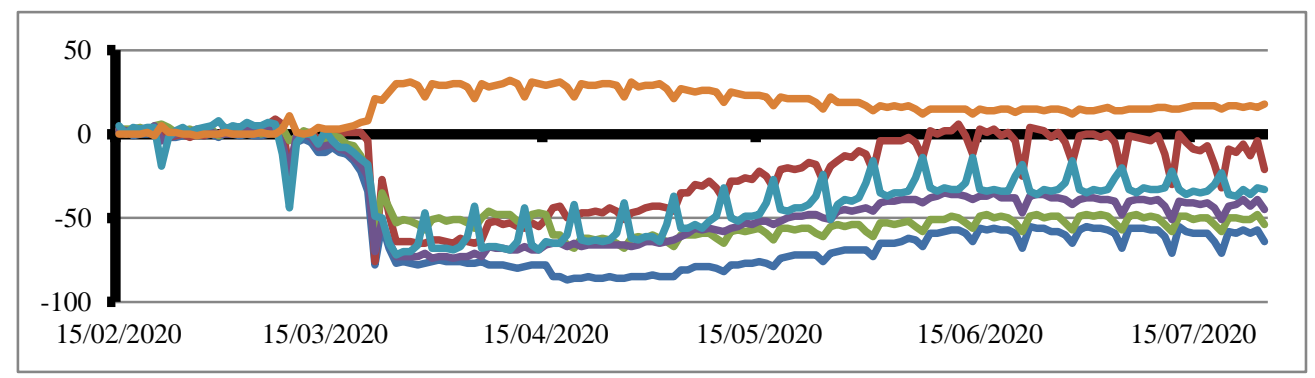

In Nigeria

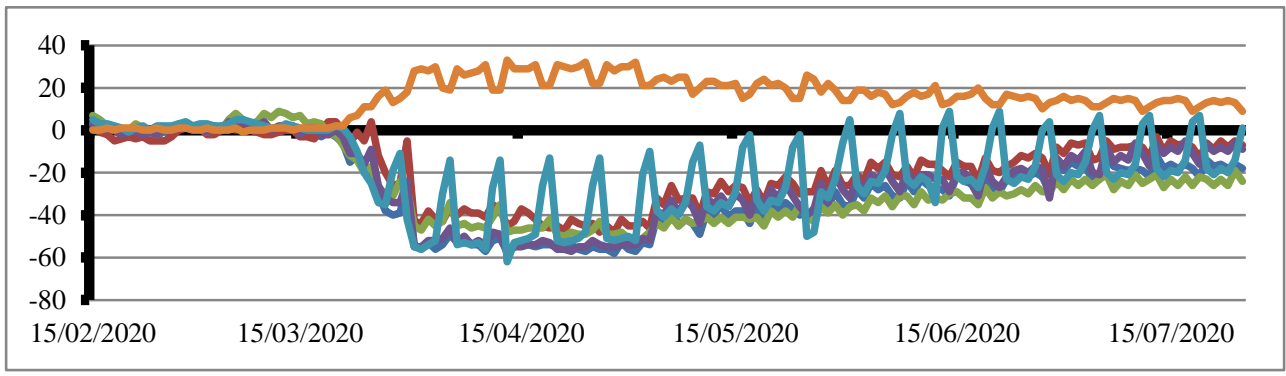

Figure 1. Social distancing for 10 countries

Source: Community Mobility Reports to COVID-19.

Kruskal-Wallis test has been used to examine the significance of variation among social distancing and digital payments measured by transactions' volumes and values. This has been conducted on 10 countries (United States, United Kingdom, Egypt, United Arab Emirates, Saudi Arabia, Japan, South Korea, Italy, India and Nigeria) during the period from March to June 2020. Table 1 illustrates this test as follows:

Table 1. Kruskal-Wallis test output for social distancing

\begin{tabular}{cccc}
\hline & Social Distancing & Tansactions' Volumes & Transactions' Values \\
\hline Chi-Square & 22.29146 & 34.37561 & 36.322 \\
df & 9 & 9 & 9 \\
Asymp. Sig. & 0.008 & $7.67 \mathrm{E}-05$ & .000 \\
\hline
\end{tabular}

Source: Outputs of data processing.

Chi-Square coefficients indicate the significance of differences among social distancing and digital payments measured by transactions' volumes and values at a significance level of 0.01 levels.

This paper aims at testing the following two hypotheses:

1- There's no significant effects of social distancing on digital payments measured by transactions' volumes.

2- There's no significant effects of social distancing on digital payments measured by transactions' values.

Regarding these 2 hypotheses, we consider the alternative hypothesis Ha: $\beta$ \# 0 versus null hypothesis Hb: $\beta=0$, where $\beta$ is the regression coefficient of the following functions:

$$
Y_{1}=\alpha+\beta_{1} X_{1}+\beta_{2} X_{2}+\beta_{3} X_{3}+\beta_{4} X_{4}+\beta_{5} X_{5}+\beta_{6} X_{6}+\varepsilon
$$




$$
Y_{2}=\alpha+\beta_{1} X_{1}+\beta_{2} X_{2}+\beta_{3} X_{3}+\beta_{4} X_{4}+\beta_{5} X_{5}+\beta_{6} X_{6}+\varepsilon
$$

\section{Testing Hypotheses}

\subsection{Examining the Effect of Social Distancing on the Digital Payments Measured by Transactions'Volumes}

This has been conducted using panel data analysis according to cross-sectional units technique and provides the following results:

Table 2. The effects of social distancing on digital payments measured by transactions' volumes

\begin{tabular}{|c|c|c|c|c|c|}
\hline \multirow{2}{*}{\multicolumn{6}{|c|}{$\begin{array}{c}\text { Model 1: WLS, using } 40 \text { observations, Included } 10 \text { cross-sectional units, Dependent variable: Y1 } \\
\text { Weights based on per-unit error variances }\end{array}$}} \\
\hline & & & & & \\
\hline & Coefficient & Std. Error & t-ratio & $p$-value & \\
\hline const & 1.61425 & 2.62386 & 0.6152 & 0.5426 & \\
\hline $\mathrm{X} 1$ & 0.319539 & 0.119692 & 2.670 & 0.0117 & $* *$ \\
\hline $\mathrm{X} 2$ & 0.557324 & 0.139815 & 3.986 & 0.0003 & $* * *$ \\
\hline $\mathrm{X} 4$ & 0.466427 & 0.122074 & 3.821 & 0.0006 & $* * *$ \\
\hline $\mathrm{X} 5$ & -1.86703 & 0.222031 & -8.409 & $<0.0001$ & $* * *$ \\
\hline $\mathrm{X} 3$ & 0.00491421 & 0.0407791 & 0.1205 & 0.9048 & \\
\hline X6 & -0.336618 & 0.412106 & -0.8168 & 0.4199 & \\
\hline \multicolumn{6}{|c|}{ Statistics based on the weighted data: } \\
\hline Sum squared resid & 35.40647 & S.E. of regression & & 1.035820 & \\
\hline R-squared & 0.905454 & Adjusted R-squared & & 0.888264 & \\
\hline$F(6,33)$ & 52.67268 & P-value $(F)$ & & $1.68 \mathrm{e}-15$ & \\
\hline Log-likelihood & -54.31784 & Akaike criterion & & 122.6357 & \\
\hline Schwarz criterion & 134.4578 & Hannan-Quinn & & 126.9102 & \\
\hline \multicolumn{6}{|c|}{ Statistics based on the original data: } \\
\hline Mean dependent var & 12.81292 & S.D. dependent var & & 14.22387 & \\
\hline Sum squared resid & 1602.114 & S.E. of regression & & 6.967705 & \\
\hline
\end{tabular}

Source: Outputs of data processing.

According to table (2), results indicate that social distancing has a significant effect on digital payments measured by transactions' volumes, with $\mathrm{R}^{2}$ of 0.8883 at a significance level of 0.01 . Findings support the significant effects of social distancing in retail and recreation (X1), grocery and pharmacy (X2), transit stations (X4) and workplaces (X5).

\subsection{Examining the Effect of Social Distancing on the Digital Payments Measured by Transactions'Values}

This has been conducted using panel data analysis according to cross-sectional units technique and provides the following results:

Table 3. The effects of social distancing on digital payments measured by transactions' values

\begin{tabular}{|c|c|c|c|c|c|}
\hline \multicolumn{6}{|c|}{ Model 2: WLS, using 40 observations, Included 10 cross-sectional units, Dependent variable: TVALUES } \\
\hline \multicolumn{6}{|c|}{ Weights based on per-unit error variances } \\
\hline & Coefficient & Std. Error & t-ratio & $p$-value & \\
\hline const & -180.364 & 504.856 & -0.3573 & 0.7232 & \\
\hline $\mathrm{X} 1$ & 96.7610 & 21.7446 & 4.450 & $<0.0001$ & $* * *$ \\
\hline $\mathrm{X} 2$ & 101.427 & 28.2849 & 3.586 & 0.0011 & $* * *$ \\
\hline $\mathrm{X} 3$ & 6.31319 & 6.32219 & 0.9986 & 0.3253 & \\
\hline $\mathrm{X} 4$ & 45.9579 & 26.9281 & 1.707 & 0.0973 & $*$ \\
\hline $\mathrm{X} 5$ & -324.609 & 37.7155 & -8.607 & $<0.0001$ & $* * *$ \\
\hline X6 & -23.7381 & 85.7933 & -0.2767 & 0.7837 & \\
\hline \multicolumn{6}{|c|}{ Statistics based on the weighted data: } \\
\hline Sum squared resid & 35.68946 & S.E. of regression & & 1.039951 & \\
\hline R-squared & 0.906694 & Adjusted R-squared & & 0.889730 & \\
\hline $\mathrm{F}(6,33)$ & 53.44603 & P-value $(F)$ & & $1.36 \mathrm{e}-15$ & \\
\hline Log-likelihood & -54.47706 & Akaike criterion & & 122.9541 & \\
\hline Schwarz criterion & 134.7763 & Hannan-Quinn & & 127.2286 & \\
\hline \multicolumn{6}{|c|}{ Statistics based on the original data: } \\
\hline S.D. dependent var & 2661.742 & Mean dependent var & & 1960.697 & \\
\hline S.E. of regression & 1484.697 & Sum squared resid & & 72742683 & \\
\hline
\end{tabular}


According to table 3, results indicate that social distancing has a significant effect on digital payments measured by transactions' values, with $\mathrm{R}^{2}$ of 0.8897 at a significance level of 0.01 . Findings support the significant effects of social distancing in retail and recreation $\left(\mathrm{X}_{1}\right)$, grocery and pharmacy $\left(\mathrm{X}_{2}\right)$, transit stations $\left(\mathrm{X}_{4}\right)$ and workplaces $\left(\mathrm{X}_{5}\right)$.

So, results supports the significant effects of social distancing on digital payments measured by each of transactions' volumes and values. This means that we can accept the alternative hypothesis and reject null hypothesis for retail and recreation, grocery and pharmacy, transit stations and workplaces, whithout any evidence about significant effects for parks and residentials.

\section{Results and Concluded Remarks}

This paper investigats the opportunities of growth under restrictions of social distancing for FinTech. This has been conducted on 10 countries (United States, United Kingdom, Egypt, United Arab Emirates, Saudi Arabia, Japan, South Korea, Italy, India and Nigeria) during the period from March to June 2020. Results indicate that social distancing may affect digital payments. This has been supported for retail and recreation $\left(\mathrm{X}_{1}\right)$, grocery and pharmacy $\left(\mathrm{X}_{2}\right)$, transit stations $\left(\mathrm{X}_{4}\right)$ and workplaces $\left(\mathrm{X}_{5}\right)$, whithout any evidence about significant effects for parks $\left(\mathrm{X}_{3}\right)$ and residentials $\left(\mathrm{X}_{6}\right)$.

The study recommends the regulatory authorities to respond quickly to the requirements for the stability of the financial system, in light of the growth of the digital payments sector, especially the ones resulting from FinTech (non-banking services) according to RegTech. Besides, it's important to take in to account fraud detection and prevention while launching Fintech platforms.

\section{References}

Alber, N. (2020a). Finance in the time of Coronavirus during 100 Days of Isolation, The Case of the European Stock Markets. https://doi.org/10.2139/ssrn.3631517

Alber, N. (2020b). The Effect of Coronavirus Spread on Stock Markets,The Case of the Worst 6 Countries. https://doi.org/10.2139/ssrn.3578080

Alber, N., \& Saleh, A. (2020). The Impact of Covid-19 Spread on Stock Markets: The Case of the GCC Countries. International Business Research, 13(11). https://doi.org/10.5539/ibr.v13n11p16

Appaya, S., Gradstein, H., \& Mathurin-Andrew, T. (2020). Fintech can help in the response to COVID-19. But where should policymakers start? World bank. Retrieved from https://blogs.worldbank.org/psd/fintech-can-help-response-covid-19-where-should-policymakers-start

Bartik, A. W., Bertrand, M., Cullen, Z. B., Glaeser, E. L., Luca, M., \& Stanton, C. T. (2020). How are small businesses adjusting to covid-19? Early evidence from a survey (No. w26989). National Bureau of Economic Research. https://doi.org/10.3386/w26989

Beaunoyer, E., Dupéré, S., \& Guitton, M. J. (2020). COVID-19 and digital inequalities: Reciprocal impacts and mitigation strategies. Computers in Human Behavior. https://doi.org/10.1016/j.chb.2020.106424

Camacho, N., Nam, H., Kannan, P. K., \& Stremersch, S. (2019). Tournaments to crowdsource innovation: The role of moderator feedback and participation intensity. Journal of Marketing, 83(2), 138-157. https://doi.org/10.1177/0022242918809673

Chetty, R., Friedman, J. N., Hendren, N., \& Stepner, M. (2020). How did covid-19 and stabilization policies affect spending and employment? A new real-time economic tracker based on private sector data (No. w27431). National Bureau of Economic Research. https://doi.org/10.3386/w27431

Chishti, S. (2016). How peer to peer lending and crowdfunding drive the fintech revolution in the UK. In Banking beyond banks and money (pp. 55-68). Springer, Cham. https://doi.org/10.1007/978-3-319-42448-4_4

D'Acunto, F., Rossi, A., \& Weber, M. (2019). Crowdsourcing financial information to change spending behavior. Chicago Booth Research Paper, (19-09). https://doi.org/10.2139/ssrn.3339335

Goldstein, I., Jiang, W., \& Karolyi, G. A. (2019). To FinTech and beyond. The Review of Financial Studies, 32(5), 1647-1661. https://doi.org/10.1093/rfs/hhz025

Guild, J. (2017). Fintech and the Future of Finance. Asian Journal of Public Affairs, 17-20. https://doi.org/10.18003/ajpa.201710

Hendriyani, C., \& Raharja, S. U. J. (2019). Business Agility Strategy: Peer-to-Peer Lending of Fintech Startup in 
the Era of Digital Finance in Indonesia. Review of Integrative Business and Economics Research, 8, 239-246.

International Monetary Fund and World Bank. (2018). The Bali Fintech Agenda: Chapeau Paper. Working Paper no. 130563. Washington, D.C.: World Bank Group.

Jagtiani, J., \& Lemieux, C. (2017). Fintech lending: Financial inclusion, risk pricing, and alternative information. FRB of Philadelphia Working Paper No. 17-17. https://doi.org/10.21799/frbp.wp.2017.17

Jiang, J., Liao, L., Wang, Z., \& Zhang, X. (2018). Government Affiliation and Fintech Industry: The Peer-to-Peer Lending Platforms in China. Working Paper SSRN 3116516. https://doi.org/10.2139/ssrn.3116516

Kunz, S., \& Muralidhar, A. (2017). InvestTech and Crowdsourcing Best Ideas: Investment Strategies for a Low-Yield Environment. Working paper SSRN 2899425. https://doi.org/10.2139/ssrn.2899425

Mahardhika, G. S., \& Inggis, R. A. (2017). Peer to Peer Lending in Surabaya: How It Drives Regional Economy? Journal of Development Economics, 2(2), 58-78. https://doi.org/10.20473/jde.v2i2.6552

Navaretti, G. B., Calzolari, G., Mansilla-Fernandez, J. M., \& Pozzolo, A. F. (2018). Fintech and Banking. Friends or Foes? Friends or Foes. Working paper SSRN 3099337. https://doi.org/10.2139/ssrn.3099337

Nicola, M., Alsafi, Z., Sohrabi, C., Kerwan, A., Al-Jabir, A., Iosifidis, C., ... \& Agha, R. (2020). The socio-economic implications of the coronavirus and COVID-19 pandemic: A review. International Journal of Surgery. https://doi.org/10.1016/j.ijsu.2020.04.018

Peterson, K \& Ozili, T. (2020). Spillover of COVID-19: Impact on the Global Economy. Retrieved from https://papers.ssrn.com/sol3/papers.cfm?abstract_id=3562570

Puschmann, T. (2017). Fintech. Business \& Information Systems Engineering, 59(1), 69-76. https://doi.org/10.1007/s12599-017-0464-6

Smales, L. (2020). Investor Attention and the Response of US Stock Sectors to the COVID-19 Crisis. http://dx.doi.org/10.2139/ssrn.3625487

Sul, E. (2020). Effects of FinTech and Crowdsourced Forecasting on Firms: Evidence from Estimize. Working paper SSRN 3573152. https://doi.org/10.2139/ssrn.3573152

Thakor, A. V. (2020). Fintech and banking: What do we know? Journal of Financial Intermediation, 41, 100833. https://doi.org/10.1016/j.jfi.2019.100833

\section{Copyrights}

Copyright for this article is retained by the author(s), with first publication rights granted to the journal.

This is an open-access article distributed under the terms and conditions of the Creative Commons Attribution license (http://creativecommons.org/licenses/by/4.0/). 